\title{
P103: Contamination risk of alcohol-based hand disinfectants and skin antiseptics with bacterial spores
}

\author{
K Steinhauer $^{1^{*}}$, B Meyer $^{2}$, C Ostermeyer ${ }^{3}, \mathrm{H}-\mathrm{J}$ Rödger $^{4}$, M Hintzpeter $^{5}$ \\ From 2nd International Conference on Prevention and Infection Control (ICPIC 2013) \\ Geneva, Switzerland. 25-28 June 2013
}

\begin{abstract}
Introduction
Alcohol-based products are regarded as most appropriate in hand disinfection and in skin antisepsis. While alcohols have an immediate microbicidal effect against all vegetative microbial forms, they do not readily kill bacterial spores. This fact raised the question of the contamination risk of alcohol-based hand disinfectants and skin antiseptics with bacterial spores.
\end{abstract}

\section{Objectives}

The aim of this study was to evaluate the overall risk of hand disinfectants and skin antiseptics to get contaminated with bacterial spores throughout the production process. Additionally the risk of contamination with bacterial spores throughout the subsequent in-use period was investigated.

\section{Results}

Besides raw materials, primary packaging was identified as a potential source of bacterial spores. Investigation of a total of 625 containers did not yield any microbial growth in 542 cases. Median colony count for aerobic spore-forming bacteria was $0.2 \mathrm{cfu} / 10 \mathrm{ml}$ container content. No anaerobic spore-forming bacteria were detected.

Additionally, long-term survival of bacterial spores in aliphatic $\mathrm{C} 2-\mathrm{C} 3$ alcohols was investigated. 1-propanol was found to reduce the number of spores most effectively, with 2-propanol and ethanol having a somewhat less pronounced impact. Thus 1-propanol was found to give reduction rates of $1.35 \mathrm{lg}$ after 7 weeks contact time at a concentration of $30 \%(\mathrm{v} / \mathrm{v})$, and viability of $B$. subtilis spores was further decreased to > $1.5 \lg$ by $30 \%$ (v/v) 1-propanol after 14 weeks.

'Product Development Hygiene / Bioscience, Schülke \& Mayr GmbH, Norderstedt, Germany

Full list of author information is available at the end of the article
Exemplary in-use tests of a typical hand disinfectant and a typical skin antiseptic did not detect any microbial contamination or change in the physico-chemical properties of the tested products over 12 months.

\section{Conclusion}

Investigation of primary packaging material and in-use were found not to pose a hygienic risk for typical alcohol-based disinfectants regarding bacterial spores. Data from this study revealed that hygienic safety regarding contamination with bacterial spores can be achieved if appropriate production processes are in place. In order to control hygienic safety of alcohol-based hand rubs and antiseptics, a microbial limit of $<1 \mathrm{cfu} / 10 \mathrm{ml}$ is suggested as a quality-control threshold for finished goods.

\section{Disclosure of interest}

K. Steinhauer Employee of Schülke \& Mayr GmbH, B. Meyer Employee of Ecolab Deutschland GmbH, C. Ostermeyer Employee of Bode Chemie GmbH, H.-J. Rödger Employee of Lysoform Dr. Hans Rosemann GmbH, M. Hintzpeter Employee of B. Braun Melsungen AG.

\section{Author details \\ 'Product Development Hygiene / Bioscience, Schülke \& Mayr GmbH, Norderstedt, Germany. ${ }^{2}$ Ecolab Deutschland GmbH, Düsseldorf, Germany. ${ }^{3}$ Bode Chemie $\mathrm{GmbH}$, Hamburg, Germany. ${ }^{4}$ Lysoform Dr. Hans Rosemann GmbH, Berlin, Germany. ${ }^{5}$ B. Braun Melsungen AG, Melsungen, Germany.}

Published: 20 June 2013

doi:10.1186/2047-2994-2-S1-P103

Cite this article as: Steinhauer et al:: P103: Contamination risk of alcohol-based hand disinfectants and skin antiseptics with bacterial spores. Antimicrobial Resistance and Infection Control 2013 2(Suppl 1):P103.

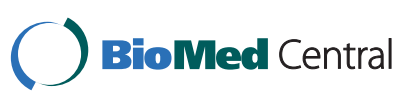

(C) 2013 Steinhauer et al; licensee BioMed Central Ltd. This is an Open Access article distributed under the terms of the Creative Commons Attribution License (http://creativecommons.org/licenses/by/2.0), which permits unrestricted use, distribution, and reproduction in any medium, provided the original work is properly cited. 